\title{
Utilizing Relational Governance in Export Relationships: Leveraging Learning and Improving Flexibility and Satisfaction
}

DOI:

10.1016/S1474-7979(05)16007-4

Link to publication record in Manchester Research Explorer

Citation for published version (APA):

Roath, A. S., \& Sinkovics, R. R. (2006). Utilizing Relational Governance in Export Relationships: Leveraging Learning and Improving Flexibility and Satisfaction. In Advances in International Marketing/Adv. Int. Mark. (Vol. 16, pp. 157-185). (Advances in International Marketing; Vol. 16). Elsevier BV. https://doi.org/10.1016/S14747979(05)16007-4

\section{Published in:}

Advances in International Marketing|Adv. Int. Mark.

\section{Citing this paper}

Please note that where the full-text provided on Manchester Research Explorer is the Author Accepted Manuscript or Proof version this may differ from the final Published version. If citing, it is advised that you check and use the publisher's definitive version.

\section{General rights}

Copyright and moral rights for the publications made accessible in the Research Explorer are retained by the authors and/or other copyright owners and it is a condition of accessing publications that users recognise and abide by the legal requirements associated with these rights.

\section{Takedown policy}

If you believe that this document breaches copyright please refer to the University of Manchester's Takedown Procedures [http://man.ac.uk/04Y6Bo] or contact uml.scholarlycommunications@manchester.ac.uk providing relevant details, so we can investigate your claim.

\section{OPEN ACCESS}




\title{
UTILIZING RELATIONAL GOVERNANCE IN EXPORT RELATIONSHIPS: LEVERAGING LEARNING AND IMPROVING FLEXIBILITY AND SATISFACTION
}

\author{
Anthony S. Roath and Rudolf R. Sinkovics
}

\section{INTRODUCTION AND PROBLEM}

Exporting manufacturers that pursue international expansion via foreign distributors face a trade off. Their decision to utilize international distributors as a market entry mode reduces some risks; however, the manufacturers do not enjoy control of the foreign channel. Given heterogeneity in global environments and often a significant geopolitical separation between manufacturers and international distributors, the ability to control the behavior of channel partners is inherently reduced. Consequently, natural conditions for opportunistic behavior are created (Karunaratna \& Johnson, 1997; Klein \& Roth, 1990).

Mechanisms that help to offset opportunism include contract enforcement, forward integration (Klein, Frazier, \& Roth, 1990), and management strategies including product and territorial exclusivity and information exchange (Karunaratna \& Johnson, 1997). However, the enforcement of

Relationship between Exporters and their Foreign Sales and Marketing Intermediaries Advances in International Marketing, Volume 16, 157-185

Copyright (C) 2006 by Elsevier Ltd.

All rights of reproduction in any form reserved

ISSN: 1474-7979/doi:10.1016/S1474-7979(05)16007-4 
contractual agreements is often difficult to rely upon, given the diversity of the economic, legal, and political markets. While contracts are signed in most business dealings, they are seldom used (Roxenhall \& Ghauri, 2004). Furthermore, manufacturers may not be willing to inherit the commitment associated with increasing variations of forward integration. The Uppsala behavioral model of Internationalization (Johanson \& Vahlne, 1977, 1990) suggests that firm's resource commitment to foreign markets gradually increases as they develop their knowledge of foreign markets. The underlying basis of the model points to an established sequence of stages that are indicative of increasing resource deployment in the host market. Accordingly, we chose to investigate learning orientation, which we believe to be an important strategy as a firm enters a host market. Essentially, the governance of the interactive relationship leads to certain outcomes based upon the learning objectives.

The focus of this study is on a cross-sectional analysis of manufacturing exporters and their partners, the foreign distributors, within the dynamic perspective of the Uppsala model. The study examines how the employment of relational governance mechanisms may help to offset opportunism while building satisfaction with the relationships as well as flexibility within the market. The approach is based upon the notion that relationships are fundamentally grounded in social interactions (Cova \& Salle, 2000) that eventually exploit organizational interdependencies and are designed to achieve strategic or market objectives.

Hence, the basis of this research is on the role of an organization's learning orientation, which is leveraged by governance mechanisms (i.e., resource commitment and trust) to achieve relationship satisfaction and flexible market capability. Relational governance both facilitates and augments learning between cross-border organizations and is seen to instrumentally counter the dangers associated with the foreign distributor's potential opportunistic behavior. Relational governance contributes to organizational flexibility in foreign markets and promotes satisfactory relationship outcomes, which underlies the firm's desire to continue the relationship while supporting the development of global strategy (Kogut, 1985).

The link between learning orientation and manufacturer commitment is related to and parallels the Uppsala link between an organization's experiential knowledge (of foreign markets) and its resource commitment to the market (Johanson \& Vahlne, 1977, 1990). However, this study explores a different perspective of learning. In fact, when contrasting the Uppsala perspective to the present definition, the study presumes a more proactive learning approach than Uppsala's concept of learning (Forsgren, 2002). 
The Uppsala perspective refers to two different types of knowledge: (1) objective knowledge, which can be learned through formal training or market research, and (2) experiential knowledge, which can only be acquired through personal experience. Uppsala deals more or less exclusively with experiential learning (Forsgren, 2002). The present research's perspective is proactive and focuses on the manufacturer's aggressive search for market solutions.

The Uppsala behavioral perspective of Internationalization involves almost a 'default' progression of increased market investment as the firm 'learns' about the market over time. The learning orientation perspective, which is used in this paper, however, implies that the manufacturer objectively puts into place an interorganizational environment that promotes market knowledge gains. Consequently, the manufacturer leverages this learning orientation with relational governance mechanisms (tools) which, if employed effectively, help to develop capabilities (e.g., flexibility) and secure relationships (e.g., maintain satisfying relationships). Achieving these goals helps the company to deal with the increased competitive challenges in the foreign environment. Hence, our perspective suggests that the manufacturer 'balances' the inherent tradeoff with lower-level market commitment and reduced risks, yet higher "intangible commitments" (Hadjikhani, 1997).

Consequently, this study examines two distinct relational governance mechanisms, relationship commitment and trust. The Uppsala Internationalization model is incorporated to explore the issues associated with an exporting manufacturer's overarching strategic objective of achieving effective market entry through a proactive approach involving market learning. Market learning is enhanced through governance.

\section{PURPOSE}

The purpose of the research is to assess the role of relational governance in an exporting manufacturer-international distributor relationship. The objective is to determine whether certain relational governance mechanisms can provide alternative pathways to traditional mechanisms of dealing with distributor opportunism, such as forward integration and increasing marketing commitment via sales subsidiaries or manufacturing. The impact of relational governance on flexibility and the relationship-specific attribute of satisfaction with the relationship will be examined. Flexibility contributes to competitive advantages, whereas satisfaction indicates a surrogate measure to continue working with the relationship to provide and enhance the potential for future value. Subsequently, the model is presented which proposes the exporting 
manufacturer utilizes relational governance to augment an active learning orientation to gain enhanced performance in the foreign environment.

\section{CONCEPTUAL FRAMEWORK}

The Uppsala Internationalization model, which is predicated upon the behavioral theory of the firm (Aharoni, 1966; Cyert \& March, 1963) and Penrose's (1959) theory of the growth of the firm, perceives internationalization to be a process of increased involvement. As firms develop additional levels of knowledge about foreign markets and operations, they increasingly commit resources to foreign markets (Johanson \& Vahlne, 1977). The model encompasses state and change aspects of internationalization, which build upon and reinforce each other in a causal cycle. Market commitment and market knowledge represent state aspects and current business activities, and commitment decisions characterize change aspects (Johanson \& Vahlne, 1990). Two kinds of knowledge are distinguished, objective knowledge which can be learned by formal training or market research, and experiential knowledge which can only be acquired through personal experience. The model claims that a company's engagement in a specific country market develops according to an establishment of a chain of events which reflects increasing resource commitment to the market. Using the Uppsala model as a background for understanding the mechanisms of initiating and maintaining international distributor relationships would lead us to conclude that exporting manufacturers may resort to forward integration and acquisition strategies to deal with opportunistic, performance weakening distributor behavior almost by default. However, the present study follows a relational governance approach to managing export manufacturer-foreign distributor interactions. It builds upon the notion that proactive management of the relationship augments learning that may, in turn, provide an alternative to forward integration while contributing to relationship satisfaction and an ability to be flexible in the market.

Researchers in the international business marketing and channel management literature have increasingly drawn their attention to relational aspects of manufacturer and distributor interaction (Bello \& Gilliland, 1997; Heide, 1994). Most of the research has focused on explaining how interorganizational management processes are dependent upon relational interaction such as cooperation, trust, and commitment (Gundlach, Achrol, \& Mentzer, 1995; Morgan \& Hunt, 1994). Additionally, some scholars have 
investigated direct linkages between the relational attributes of interorganizational structures and economic performance (Bello \& Gilliland, 1997; Celly \& Frazier, 1996; Lusch \& Brown, 1996). Rationales for these investigations are grounded in the recognition that companies strive to reduce the transaction and agency costs inherent to the relationship. Furthermore, scholars and practitioners are aware that the successful governance of relationships provides a foundation to develop self-enforcing mechanisms that ultimately help to protect assets and reduce monitoring costs (Conn \& Yip, 1997; Drucker, 1995). Indeed, some research has examined relational processes, such as cooperation, relational commitment, and trust as primary variables impacting performance (Lusch \& Brown, 1996; Zaheer \& Venkatraman, 1995).

Furthermore, the relationship marketing literature argues that close, collaborative relationships between parties lead to beneficial outcomes for all. The tangible and intangible elements of the relationship that are created from close collaboration between firms (i.e., associated with commitment and trust) are key sources of competitive advantages, especially if they become relationship-specific assets (Dyer \& Singh, 1998). Relationships include hard assets and resources that partners share as well as intangible components represented by knowledge-sharing routines, governance mechanisms, and relationship-specific assets. The conceptual framework presents a synthesis of the literature on relationship marketing, the resource-based view of the firm, and transaction cost economics (illustrated in Fig. 1). This model directs our empirical work and integrates relationship marketing perspectives with the governance of export manufacturer-distributor relationships. The factors are presented in more detail via hypothesized relationships. $^{1}$

International channel management depends to a great degree upon an implicit or normative form of control. This form of control helps to coordinate activities between organizations as it facilitates the development of an interorganizational culture of shared beliefs (Dwyer, Schurr, \& Oh, 1987; Weitz \& Jap, 1995). The propensity to collaborate is encouraged as a result of companies that have a history of positive experiences working with each other. Firms' interactions contribute further to the reinforcement of normative forms of governance control. In addition, the evidence from these normative forms implies that the parties seek the benefits that reflect longterm opportunities and profits from the relationship. The partners enhance the potential for achieving strategic goals through relationship marketing, which contributes, in part, to their ability to adapt to changing market situations (i.e., flexibility). 


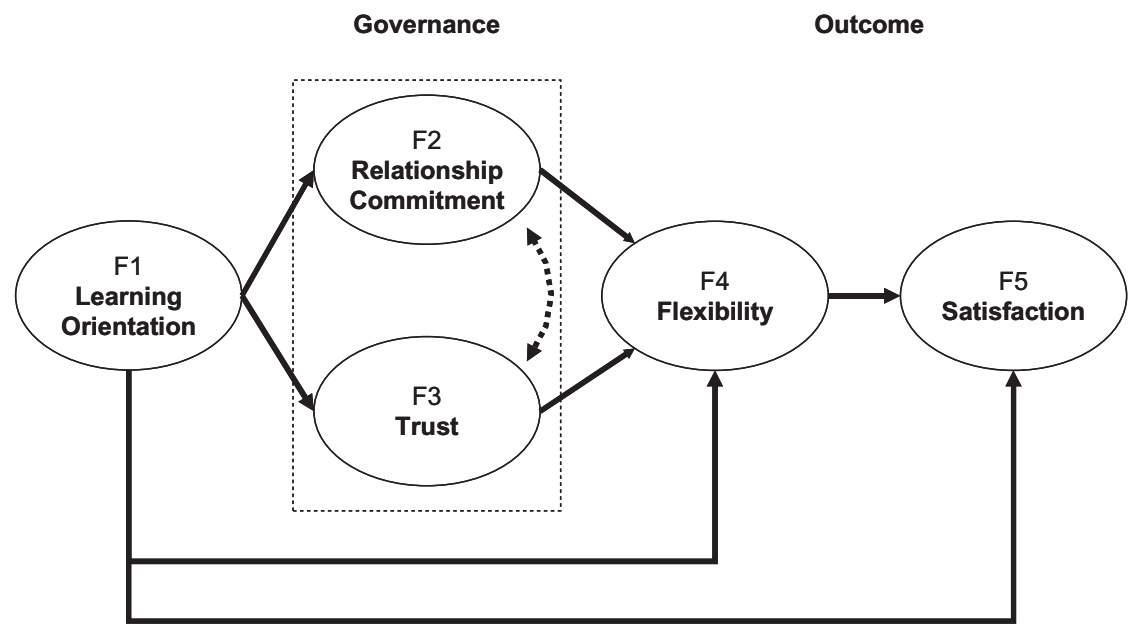

Fig. 1. Conceptual Model.

\subsection{Learning Orientation}

Weitz and Jap (1995) assert that organizations must work together to develop the factors of their relationship that underlie commitment and trust (i.e., relational norms). Bartlett and Ghoshal (1998) corroborate much of the sentiment of Weitz and Jap's (1995) position through a study highlighting this interorganizational trend: the focus of managers in international organizations has shifted from organizational planning to an increased emphasis on organizational learning. This particular proposition suggests that relational norms can contribute to factors leading to interorganizational capabilities. Indeed, companies strive to develop comprehensive organizational capabilities to help them fully understand, interpret, and respond to environmental circumstances. Therefore, developing these relational norms would strengthen the interdependencies that support relationship-specific assets.

The goal of developing interorganizational learning capabilities contributes to the working relationship between partners. In contrast to the somewhat passive and reactive form of learning associated with the Uppsala model of firm internationalization (Johanson \& Vahlne, 1977, 1990), this paper posits an active perspective. This view encompasses the notion of exporting manufacturers sharing fresh ideas with international distributors and encouraging distributors to participate in joint training activities and programs that are designed to improve mutual learning (Hult \& Ferrell, 
1997). Hence, learning orientation is not exclusively the domain of experiential learning, it is also a dimension which focuses on the search for new solutions and opportunities (Huber, 1991). Under this context, wherein geopolitical separation from distributors poses challenges to learning, an active approach helps to create opportunities to foster relationship commitment and trust. Learning creates an environment whereby the partners understand and appreciate the benefits that potentially can accrue from interfirm cooperation. This can be critical for guaranteeing core competencies and enhancing competitive advantage (Hamel, 1991).

Building an interfirm environment that encourages the development of competencies through investing in learning and knowledge dissemination contributes to enhancing the sustainability of single organizations as well as interorganizational stability (Cavusgil, 1998). The idea is grounded on the basis of mutual partner commitment, trust, and a willingness to work with each other. Furthermore, Gold, Malhotra, and Segars (2001) set forth the argument that organizations must develop an environment that stresses the existence and magnitude of knowledge management in order to achieve success. Within the context of the international supply chain, learning orientation can be integrated between the firms to represent one of the most essential ways to develop strategic capability and competitive advantage (Nonaka, 1994). Hence, relationship commitment and trust serve within the relationship marketing context as viable governance mechanisms. Consequently, a direct relationship between learning orientation and relationship marketing (i.e., relationship commitment and trust) is posited.

H1. Learning orientation will positively impact the governance of the export manufacturer-international distributor relationship; hence learning orientation results in higher levels of relationship commitment.

In a similar vein, we argue that,

H2. Learning orientation will result in higher levels of export manufacturer trust in a foreign distributor.

\subsection{Relational Governance}

Weitz and Jap (1995) posit that the focus of practitioners in their approach to channel relationship management has shifted. Managers have reduced their emphasis on governing corporate channel structures through the use of power and dependence. As a result of these changes, managers have increased their interest in managing the relationship by investing in the 
development of relational norms. These relational norms are advanced through "self-governance" mechanisms that help reduce an organization's transaction and agency costs. In addition, relational norms are idiosyncratic, which implies that the manner in which a firm maintains its relationships could contribute to competitive capability. The present study adopts Heide's (1994) view of governance, which he envisions to be a multidimensional interaction between two partners that embodies all aspects of relationship management and maintenance. This perspective is extended to define governance as a series of management decision-making processes that a firm may use within the relationship to affect desired objectives.

Under this definition, governance is an integration of relationship commitment and trust, which Morgan and Hunt (1994) refer to as relationship marketing. Relationship commitment and trust separately are forms of governance, which the manufacturer employs when managing the relationship. Trust and relationship commitment are both rational means to improve the governance of the relationship yet they may also complement each other. Relationship commitment represents a tangible demonstration or intention to work with the partner, whereas trust implies that the partner is willing to work with the other under the auspices of mutual respect and the implication that vulnerabilities would not be exploited. Hence, these relational variables represent a hybrid form of governance.

\subsubsection{Relationship Commitment}

Relationship commitment is the willingness of partners to make sacrifices when working together to achieve particular goals. It has been defined as an "implicit or explicit pledge of relational continuity between exchange partners" (Dwyer \& Oh, 1988). Gundlach et al., (1995), echoing Macneil (1980), argue that commitment is an important element of a long-term and regulated exchange relationship. In addition, Morgan and Hunt (1994) define commitment as a partner's willingness to place maximum effort into maintaining the relationship because of the belief that the relationship is worthy enough to ensure it endures indefinitely. Consequently, commitment seems to reinforce the social norms between the organizations, which in turn, contribute to effective long-term relationship exchange. This follows the concept that relationship commitment represents a deeper resolve between the parties to maintain the relationship (Dwyer et al., 1987). Morgan and Hunt (1994) support this consensus in the marketing channel literature by presenting the notion that organizations demonstrate their resolve by investing in the relationship to make the collaboration effort successful and competitive. Again, this investment leads to relationship-specific assets that 
are enhanced through trust. Part of the relationship reinforcement is indeed grounded in trust as trust is argued in the social exchange literature to be one of the central elements to all relational exchanges (Anderson \& Narus, 1990; Ganesan, 1994; Morgan \& Hunt, 1994).

\subsubsection{Trust}

Trust has been investigated as a key component of relationships and an effective tool that the partners use to govern their relationship, both in national (see e.g., Doney \& Cannon, 1997; Geyskens, Steenkamp, \& Kumar, 1998; Zaheer, McEvily, \& Perrone, 1998) and international contexts (e.g., Aulakh, Kotabe, \& Sahay, 1996; Boersma, Buckley, \& Ghauri, 2003; Dyer $\& \mathrm{Chu}, 2000)$. The concept of trust in the literature is considered to have many dimensions. For example, two defining dimensions of trust are benevolence and credibility. The credibility dimension of trust outlines the confidence the partners have with each other after working together over time. Essentially, it is an indication that the partners have developed a degree of operational efficiency and the ability to work together (Ganesan, 1994). The benevolent aspect of trust indicates a willingness to show good faith toward the other. It is the extent to which partners express good intentions to the other without expressing specific commitments. In this case, trust is a developed mutual confidence that no partner will exploit the other (Sabel, 1993). It therefore expresses a willingness to be vulnerable to the actions of another party based on the expectation that the other party will perform a particular action regardless of the ability to monitor or control that other party (Mayer, Davis, \& Schoorman, 1995). Accordingly, trust is examined as a benevolence issue since it supports better the paper's proposition that the exporting manufacturer establishes a learning environment that actively utilizes relational governance. Presumably, credibility trust is developed as a result of the interaction.

Building on Gundlach et al., (1995) conceptualization, there is a positive relationship between relationship commitment and trust. The parties' commitment and desire to build a long-term relationship provides a foundation for trust. Furthermore, trust reduces uncertainty within a relationship and the perceived likelihood that one party will exploit the other (Parkhe, 1998a, b). In general, trust engenders a confidence of mutual reliance that leads to greater cooperative behavior, such as problem solving, communication, and knowledge sharing. Other intangible benefits of trust embody the idea that it promotes interorganizational cooperation (Ring \& Van De Ven, 1992). In an international setting it signals the commitment of foreign subsidiary managers (Kim \& Mauborgne, 1993). Gounaris and Venetis (2002) 
established that trust proves to be a valuable tool for maintaining the relationship with the organizational client and ensuring its longevity. Moreover, Barney and Hansen (1994) argued that trustworthiness developed between organizations could become a source of competitive advantage since the primary contribution of trust is its value to relational exchange and a precursor to beneficial relational outcomes. Empirical research confirmed the benefits of trust in many contexts (Ganesan, 1994; Lambe, Spekman, \& Hunt, 2000; Morgan \& Hunt, 1994).

The process of developing credible commitment is a vital ingredient of relationship monitoring because it mitigates opportunistic behavior (Gundlachet al., 1995; Macneil, 1980) while at the same time reduces perceived risks (Ganesan, 1994; Gruen, Summers, \& Acito, 2000). The desire to reduce risk motivates firms to invest in the relationship, which increases commitment and subsequent relationship continuity. Hence, trust between partners in a relationship would lead to firm commitment as a relationship grounded in trust is one that fosters a greater potential to achieve the benefits that occur through long-term exchanges. In the same way that trust augments commitment, relationship commitment will reinforce the levels of trust - a reciprocal and positive relationship.

H3. Relationship commitment and trust are positively related.

\subsection{Relational Governance and Flexibility}

Flexibility is the ability to modify processes in rapidly changing environments to achieve strategic objectives while at the same time lower opportunity costs and reduce path dependencies (Sanchez, 1995). The geophysical and cultural separation of manufacturer and international distributors heightens the importance of flexibility and its impact on export performance (see e.g., Ling-yee Li \& Ogunmokum, 2000). The ability to adapt to unforeseen contingencies, a crucial element of flexibility, is arguably a desired outcome of organizations because it provides a means to confront potential problems (Harrigan, 1988) as well as to recover from events that may disrupt the organization's operations (Evans, 1991). Flexibility in this context represents a good-faith effort to modify interorganizational actions when confronted with changing circumstances.

The environmental events and factors that affect one partner would potentially influence the other in a working relationship (Bello \& Gilliland, 1997; Roath, Miller, \& Cavusgil, 2002). The tangible and intangible benefits that are derived from the manufacturer's relationship commitment include 
the idea that the partners will invest in processes and procedures that will enable the partnership to swiftly adapt to environmental changes, especially since environmental dynamics may dramatically affect both parties. Relationship commitment demonstrates the resolve to develop a mutual capability to react to these changes effectively. In addition, trust between the partners is illustrated through their mutual reliance to do their part skillfully to adapt to environmental dynamics. Consequently, the governance mechanisms associated with relationship marketing are essentially tools that an organization can employ to increase the potential for achieving flexibility.

Dwyer and Oh (1988) as well as Frazier and Kale (1989), argue that satisfaction is a primary factor for evaluating channel performance. Satisfaction is not only a surrogate for the perceived effectiveness of relationship governance, satisfaction may also be predictive of future actions. For example, Nevin (1995) believes that relational exchange is a long-term process based upon recurring exchanges with the same individuals or firms. When the parties are committed to maintaining the relationship, they strive to make it work, which potentially leads to successful and mutually beneficial exchanges and outcomes. As firms work together to achieve benefits from their relationship, they also have an increased awareness or perception of compatibility and collaboration from their respective partner. The collaboration increases the ability to understand each other's processes and capacity to work together better under different environmental circumstances. Collaboration efforts demonstrate a willingness to work to fulfill desired outcomes and thus results in increased flexibility in the relationship.

Furthermore, the necessity to spend extra time and resources on monitoring efforts is diminished, thereby permitting the partners to concentrate more on developing interorganizational strengths. When faced with environmental uncertainty, the role of the governance mechanisms of relationship commitment and trust contributes to the relationship's adaptation abilities because the partners have more confidence in allowing the other to address contingencies without having to constantly provide input. In effect, lesser degrees of control relate to higher degrees of flexibility. Noordewier, John, and Nevin (1990) propose that these adaptation abilities are especially important because not having adaptive capabilities in an uncertain environment could lead to undesirable circumstances. Thus, relational governance increases the partner's confidence in the other to react independently in a beneficial relationship, even when confronted with different scenarios. This leads to the following propositions: 
H4. Effective relational governance (as evidenced by relationship commitment) contributes to flexibility with the relationship.

H5. Effective relational governance (as evidenced by trust) contributes to flexibility with the relationship.

\subsection{Flexibility and Satisfaction}

Anderson and Narus (1990) define satisfaction in manufacturer-distributor relationships as a positive result of a partner's assessment of the desired outcomes from the working partnership. According to Wilson (1995), satisfaction is one of the most critical variables in business relationships. Wilson relates satisfaction, in the context of business relationships, as the degree to which the transaction meets the performance expectations of the partner. Given this definition of satisfaction as 'expectations met,' the manufacturer will be satisfied if performance objectives are met or exceeded.

Relationships that have developed continuity and have experienced mutually beneficial outcomes typically have partners that are satisfied with the relationship. These relationships impart a degree of confidence to the partners because they demonstrate the partners' ability and desire to work together without having to be concerned about exploitation. Because the partners are satisfied with the relationship, they have a greater tendency to be cooperative and communicative. Theoharakis and Hooley (2003) provide support for the development of organizational resources that foster and enable relationships in business-to-business environments since such resources are linked with improved firm performance. Rosson and Ford (1982) demonstrated that relational outcomes are positively associated with information exchange in relationships that operate in an international environment. Moreover, Noordewier et al., (1990) empirically support their findings by providing evidence that flexible partnerships underscore the notion of communication and trust-oriented relational processes.

H6. The flexibility dimension within the export manufacturer-distributor interaction is positively associated with the relationship's satisfaction.

\subsection{Learning Orientation and Flexibility}

Flexibility is the ability to alter methods of doing business to achieve strategic objectives while at the same time lowering strategic opportunity costs in rapidly changing environments (i.e., flexibility reduces path dependencies). Flexibility represents a desired outcome of the relationship, as it is a 
good-faith effort to modify actions when confronted with changing circumstances. Learning orientation is an attempt to instill a high value on learning activities, which include seeking and sharing market knowledge. Learning orientation increases the potential to successfully confront changing circumstances because the knowledge-sharing routines that are practiced between the organizations represent a good faith effort to collaborate.

A result of cooperative behavior between the partners is information exchange. Knowledge sharing routines through learning orientation also increase access to a greater number of information sources, which offers alternative interpretations of market information (Slater \& Narver, 1995). Consequently, the coordination, manifested through a learning orientation provides the advantage of increased efficiency in information dissemination and flexibility.Essentially, learning orientation encourages each party in the partnership to make variations in their processes and with each other in order to adapt to environmental dynamics. Thus,

H7. Learning orientation encompasses greater coordination through information exchange, which contributes to a greater degree of flexibility.

To the same extent that the development of interorganizational learning capabilities contributes to the enhanced working of the relationship between parties, there will also be a direct link with satisfaction. Not only does interorganizational learning foster relationship commitment and trust, it will also directly enhance the parties perception of their mutual collaborative efforts and satisfaction of their relationship.

H8. Learning orientation is positively related to satisfaction.

\section{METHODS}

In-depth interviews with 12 experienced international marketing executives and six international trade lawyers provided valuable insights into manufacturer-distributor relationships from managers' perspectives. All executives were responsible for building and maintaining relationships with a set of foreign distributors. They were either directly involved with their company's export operations or well informed about how their firm manages foreign distributors. The lawyers were involved in the formal establishment of contracts between the parties or dealing with issues of conflict resolution with foreign distributors. Consequently, they were all very well suited for 
our research purposes and provided a useful starting point for specifying the domain of our research and questionnaire development (Churchill, 1979).

\subsection{Sampling Frame}

Contact data was purchased from the Thomas Export Directory, a large proprietary database, by selecting entries on companies actively involved in global market expansion through the use of foreign distributors. We excluded small firms (fewer than 50 employees) on the basis of their often limited experience in dealing with foreign distributors and inconclusive research findings regarding firm size and export behavior (Cavusgil, 1984; Moen, 1999). Eight hundred firms were randomly selected and a questionnaire was mailed to senior managers most familiar with conditions and terms of their distributor relationships. A follow-up mailing was sent after three weeks to improve initial response. A total of 162 surveys were returned. After removing incomplete entries, 141 responses were retained in the database for further analysis. This represents an effective response rate of approximately $20 \%$ which is quite appealing given recent reports of deteriorating response rates (Ibeh, Brock, \& Zhou 2004; Jobber, Saunders, \& Mitchell 2004) and reduces potential problems of self-selection bias (Wilson, 1999).

Responding firms represent a comprehensive industry cross-section, although response counts are skewed toward industrial machinery and electronic equipment industry. The industries include industrial machinery $(24.1 \%)$, electronics $(12.8 \%)$, chemicals $(8.5 \%)$, and telecommunications $(4.3 \%)$ among others. The use of foreign distributors in these industries is commonly found and reported (Cavusgil, 1984). Therefore, industry-specific bias was minimized, supporting possible generalizability of the hypothesized results. Non-response bias was tested following a procedure suggested by Armstrong and Overton (1977). The procedure involved testing for descriptive differences such as company sales and number of employees between early and late respondents. Comparing their answers did not reveal significant differences suggesting that non-response was not a concern for the data analysis and interpretation. Table 1 provides characteristics for the respondents.

\subsection{Measure Development}

Qualitative input from interviews with experts was complemented with information about existing scales in academic marketing, channels, and the 
Table 1. Respondent Characteristics.

\begin{tabular}{lccccl}
\hline Industry & $\begin{array}{c}\text { No. of } \\
\text { Firms }\end{array}$ & $\begin{array}{c}\text { Years of } \\
\text { Experience } \\
\text { (Mean) }\end{array}$ & $\begin{array}{c}\text { No. of Export } \\
\text { Personnel }\end{array}$ & $\begin{array}{c}\text { No. of } \\
\text { Distributors } \\
\text { (Mean) }\end{array}$ & $\begin{array}{c}\text { Country/Region of } \\
\text { Distributor }\end{array}$ \\
\hline Household appliances & 3 & 9.7 & 1.6 & 2.0 & Europe \\
Automotive & 6 & 32.8 & $3.6^{\mathrm{b}}$ & $9.0^{\mathrm{c}}$ & Europe \\
Telecommunication & 7 & 14.3 & 4.6 & 31.6 & Middle East/Africa \\
Paper/publishing & 3 & 5.6 & 2.0 & 16.3 & Pac Rim/China \\
Electronic equipment & 18 & 22.0 & $3.5^{\mathrm{d}}$ & 24.6 & Pac Rim/China \\
Pharmaceutical & 5 & 26.6 & 3.8 & 5.0 & Pac Rim/China \\
Medical equipment & 6 & 21.0 & 6.0 & 73.3 & Europe \\
Furniture & 4 & 13.2 & 17.3 & 48.2 & Pac Rim/China \\
Heavy machinery & 4 & 28.8 & 14.8 & 48.8 & Pac Rim/China \\
Industrial machinery & 34 & 29.0 & 3.1 & 23.1 & Pac Rim/China \\
Chemical & 12 & 26.9 & 20.7 & 38.2 & Europe \\
Other & 39 & 21.5 & 3.7 & 30.2 & Pac Rim/China \\
\hline
\end{tabular}

${ }^{a}$ Respondents reported the region where their "most important" distributor was located. This number reflects the highest percentage (concentration) for the particular industry. The Pacific $\mathrm{Rim} /$ China was reported as the region of the most challenging distributor $(40 \%)$ by almost all industries, followed by Europe (23.7\%) and Mexico/Central America (12.6\%).

${ }^{\mathrm{b}}$ Two companies had more than 250 people dedicated to foreign operations and were excluded from the calculation of the mean.

${ }^{\mathrm{c}}$ Two companies have more than 250 distributors and were excluded from the mean calculation.

${ }^{\mathrm{d}}$ This mean score does not include two companies with more than 100 personnel dedicated to foreign operations.

international exporting literature. Multi-item measures and constructs were derived from these literature bases and subsequently modified and refined based on insights gained during additional preliminary interviews (Homburg \& Giering, 1996). These interviews involved a number of academics and a separate group of managers who examined our modified scales for face and content validity. A questionnaire was developed and pretested on a sample of 35 respondents before further modification resulted in the final survey instrument. All items are measured using Likert-type attitudinal scales, anchored on 7-point instruments with endpoints of strongly disagree $=7$ and strongly agree $=1$. Standard procedures were employed for subsequent psychometric scale-development (Baumgartner \& Homburg, 1996; Gerbing \& Anderson, 1988). The measures used in this study and their sources are discussed subsequently; their reliability estimates and confirmatory factor analysis results are provided in Table 2.

Measures for the learning orientation scale were adapted from Hult and Ferrell (1997) who build on conceptual work from Lyles and Schwenk 
Table 2. Measurement Items and Properties.

\begin{tabular}{|c|c|c|c|c|c|}
\hline id & Item & $\mu$ & $\delta$ & $\lambda_{\mathrm{i}, \mathrm{j}}$ & $t$ \\
\hline & $\begin{array}{l}\text { Learning orientation }- \text { adapted from Hult and Ferrell }(1997)-\alpha=0.82 \text {, } \\
\rho=0.82, \mathrm{AVE}=0.53\end{array}$ & & & & \\
\hline ls1 & We strongly encourage our employees to share fresh ideas with distributors & 3.01 & 1.55 & 0.73 & 8.57 \\
\hline 1s2 & Our company works with distributors to continually improve capabilities & 3.09 & 1.56 & 0.86 & 11.59 \\
\hline 1s 3 & $\begin{array}{l}\text { We encourage our distributors to participate actively in joint training } \\
\text { activities. }\end{array}$ & 2.77 & 1.57 & 0.58 & 5.48 \\
\hline \multirow[t]{2}{*}{$1 \mathrm{~s} 4$} & $\begin{array}{l}\text { Joint training programs with our distributors are designed to improve mutual } \\
\text { learning. }\end{array}$ & 3.11 & 1.65 & 0.72 & 8.22 \\
\hline & $\begin{array}{l}\text { Relationship Commitment- }- \text { taken from Gundlach, Achrol, and Mentzer } \\
\qquad(1995)-\alpha=0.84, \rho=0.83, \mathrm{AVE}=0.63\end{array}$ & & & & \\
\hline rell & $\begin{array}{l}\text { The distributor is dedicated to improvements that benefit the relationship as a } \\
\text { whole, not just one single partner. }\end{array}$ & 3.66 & 1.57 & 0.84 & 13.46 \\
\hline rel2 & $\begin{array}{l}\text { Both firms actively work together to carry out our responsibilities and } \\
\text { commitments in this relationship }\end{array}$ & 3.48 & 1.47 & 0.82 & 11.46 \\
\hline \multirow[t]{2}{*}{ rel3 } & $\begin{array}{l}\text { Both firms invest considerable resources and time to make the relationship a } \\
\text { success }\end{array}$ & 3.53 & 1.64 & 0.72 & 10.35 \\
\hline & $\begin{array}{l}\text { Trust }- \text { adapted from Anderson and Narus }(1990)-\alpha=0.81, \rho=0.88 \text {, } \\
\quad \text { AVE }=0.64\end{array}$ & & & & \\
\hline trust1 & Our business relationship is characterized by a high level of trust & 3.46 & 1.70 & 0.90 & 18.83 \\
\hline trust2 & We trust the distributor to remain within the terms of the contract & 3.33 & 1.51 & 0.76 & 9.78 \\
\hline trust3 & $\begin{array}{l}\text { Whenever the distributor offers us advice, we believe he is sharing his best } \\
\text { judgment }\end{array}$ & 3.05 & 1.41 & 0.78 & 10.62 \\
\hline
\end{tabular}


Satisfaction - adapted from Cullen, Johnson, and Sakano (1995) $-\alpha=0.82$, $\rho=0.82, \mathrm{AVE}=0.53$

sat1 We are highly satisfied with the distributor's performance compared with our initial expectations

sat2 We intend to continue the relationship with this partner for the foreseeable future

sat3 Our perception is that the distributor views our relationship as mutually beneficial

sat4 We believe that the distributor needs to improve operational processes in several areas before we renew our contract (r)

$\begin{array}{llll}4.38 & 1.71 & 0.78 & 11.86 \\ 3.12 & 1.75 & 0.76 & 9.99 \\ 3.01 & 1.45 & 0.61 & 7.48 \\ 3.91 & 1.91 & 0.76 & 13.20\end{array}$

Flexibility - taken from Heide and John (1992) $-\alpha=0.78, \rho=0.78$,

$$
\mathrm{AVE}=0.55
$$

flex 1 The distributor has not helped to increase our flexibility in servicing this market (r)

flex2 Together, we have developed processes to increase flexibility in response to customer requests

flex3 We are unable to make adjustments in our relationship to accommodate changing circumstances $(\mathrm{r})$

$\begin{array}{lrrr}3.67 & 1.95 & 0.76 & 11.86 \\ 3.46 & 1.64 & 0.75 & 11.60 \\ 2.87 & 1.49 & 0.71 & 9.62\end{array}$

Note: All items formulated as Likert-type attitudinal statements, anchored on a 7-point scale (endpoints: strongly disagree $=7$ and strongly agree $=1) . \mu$ means, $\delta=$ standard deviations, $\lambda=$ factor-loading lambda, $t=$ t-value, $\alpha=$ Cronbach alpha, $\rho=$ Jöreskog's rho, $\mathrm{AVE}=$ average variance extracted. Measurement fit: $\chi^{2}(\mathrm{df})=280$ (123); Satorra-Bentler scaled $\chi^{2}$ (df) $=242.25$ (123); $p<0.001$; Comparative Fit Index (CFI) $=0.902$; Bentler-Bonnet Non-Normed Fit Index $=0.878$; Bollen (IFI) Fit Index $=0.904$; Root mean-square error of approximation (RMSEA) $=0.084$ 
(1994). Thus, learning orientation is conceptualized as the extent to which an organization actively manages learning among its employees and encourages the incorporation of new ideas from the learning process. Relationship commitment is defined as the demonstration of the desire to develop a long-term relationship with exchange partners by investing in assets that are specific to the relationship (Anderson \& Weitz, 1992; Morgan \& Hunt, 1994). Items pertaining to the attitudinal component were taken from Gundlach et al., (1995). Four items were adapted from Anderson and Narus (1990) to capture trust and assess loyalty between manufacturer and foreign distributor. Trust is defined as the willingness to show good faith in each other and demonstrate benevolence in either party (Moorman, Deshpande, \& Zaltman, 1993). Flexibility is defined as the degree to which the relationship is able to adjust to contingencies in the environment. Items were taken from Heide and John (1992). Measures for satisfaction were extracted from Cullen, Johnson and Sakano (1995), conceptualizing satisfaction in a manufacturer-foreign distributor relationship as a positive assessment of the desired outcomes (Anderson \& Narus, 1990), i.e., the degree to which the manufacturer's relationship is better than previously expected (Cullen et al., 1995).

\subsection{Measure Assessment}

Table 3 outlines the summary statistics and correlation matrix for the measurement scales. Coefficient alphas range between 0.78 and 0.84 , which is within the limits of desirable/excellent boundaries for scales (DeVellis, 1991). A confirmatory factor analysis using EQS 6.1 was performed (Bentler $\& \mathrm{Wu}, 2003)$. The Satorra-Bentler scaled $\chi^{2}$ test, which corrects for distortions of the normal theory method when data are not normal (Satorra \& Bentler, 1988, 1994) is statistically significant $\left(\chi^{2}(123)=242.25, p=0.000\right)$. This undesirable result is considered unproblematic given the relatively small sample size and satisfactory additional fit indices. The comparative fit index (CFI), Bentler-Bonnet non-normed fit index (BBNFI), and Bollen's incremental fit index (IFI) indicate a relatively good fit for the measurement model $(\mathrm{CFI}=0.902$; BBNFI $=0.878$; IFI $=0.902)$. The root mean-square error of approximation (RMSEA) also provides support on the upper limit of the acceptable range (RMSEA $=0.084)$.

Confirmatory factor analysis assesses content, discriminant, and convergent validity. All factor loadings exceeded 0.5 ; indicating content validity (Bollen, 1989). A 95\% confidence interval was constructed around the 
Table 3. Descriptive Statistics and Construct Intercorrelations.

\begin{tabular}{lccccc}
\hline & $(1)$ & $(2)$ & $(3)$ & $(4)$ & $(5)$ \\
\hline $\begin{array}{l}\text { (1) Learning } \\
\quad \text { orientation }\end{array}$ & 1.00 & & & & \\
$\begin{array}{l}\text { (2) Relationship } \\
\quad \text { commitment }\end{array}$ & $0.226(0.110)$ & 1.00 & & & \\
(3) Trust & $0.268(0.111)$ & $0.803(0.062)$ & 1.00 & & \\
(4) Satisfaction & $-0.057(0.106)$ & $0.914(0.036)$ & $0.747(0.055)$ & 1.00 & \\
(5) Flexibility & $0.366(0.123)$ & $0.747(0.067)$ & $0.730(0.056)$ & $0.794(0.064)$ & 1.00 \\
Mean & 11.93 & 10.67 & 13.53 & 14.39 & 9.99 \\
SD & 5.04 & 11.93 & 5.45 & 5.52 & 4.25 \\
$\alpha$ & 0.82 & 0.84 & 0.81 & 0.82 & 0.78 \\
$\rho$ & 0.82 & 0.83 & 0.88 & 0.82 & 0.78 \\
AVE & 0.53 & 0.63 & 0.64 & 0.53 & 0.55 \\
\hline
\end{tabular}

Note: $\alpha=$ Cronbach alpha; $\rho=$ Jöreskog's rho; AVE $=$ average variance extracted, all correlations except a are significant at $p<0.01$; correlations among independent variables reported in the lower diagonal; standard errors reported in parentheses.

estimates of correlations between the latent constructs. To the extent that the results do not include 1.0, this test provides some evidence of discriminant validity (Anderson \& Gerbing, 1988; Bagozzi \& Yi, 1988). In addition, a more stringent test was conducted to demonstrate discriminant validity. This involved examination of the amount of variance extracted by each construct (taking measurement error into account) in relation to the squared-correlation between pairs of constructs. All pairs of factors passed Fornell and Larcker's (1981) test, providing evidence of discriminant validity among the measures.

The established measures were used to perform additional descriptive analyses. Bivariate product-moment correlations were calculated to investigate whether the following were correlated: the number of years manufacturers had international activities, the number of distributors the manufacturers held outside the US, and the number of people in manufacturers' organizations dedicated to managing foreign distributors. In line with expectations and suggestions from the Uppsala behavioral model of internationalization, all these variables were positively and significantly correlated. Thus, as manufacturers' experience in international markets evolved over time, their commitment to the markets, as represented by the number of people in home offices dedicated to managing distributors $(r=0.175, p<0.05)$, increased. The number of distributors increased $(r=0.330, p<0.01)$ as well. Furthermore, correlations were performed to 
investigate whether learning orientation differed or the governance mechanisms differed according to the respective descriptors, experience, and number of distributors or export personnel. However, no such differences emerged.

\section{RESULTS}

The hypothesized model was estimated using structural equation modeling techniques (SEM) with Bentler's (2003) EQS 6.1 program. The results of the analysis and hypotheses tests are reported in Table 4 . The overall fit measures suggest that the hypothesized model provides a reasonably good fit for the data, which is particularly encouraging when considering the attenuation in fit measures based on relatively small samples. The Satorra-Bentler scaled $\chi^{2}$ test (Satorra $\&$ Bentler, 1988, 1994) is statistically significant at the $1 \%$-level $\left(\chi^{2}(127)=244, p=0.000\right)$. However, CFI and Bollen's IFI indicate a within-threshold fit for the measurement model (CFI $=0.901$; IFI $=0.903)$. RMSEA was within the boundary of usually reported empirical research $(\mathrm{RMSEA}=0.083)$. The hypothesized relationships are illustrated graphically in Fig. 2. Of the eight hypothesized relationships, six relationships were supported at a level 0.05 statistical significance.

The relationship between learning orientation and relationship commitment $(\mathrm{H} 1)$ is not supported. The manufacturer may create a relationship environment that encourages learning between the partners, but the distributor may not necessarily reciprocate by committing its resources. Rather, the distributor may opportunistically take advantage of the information the manufacturer offers. Again, it is the manufacturer that is determined to enter the foreign market and would incur more risk relative to the foreign distributor. Learning Orientation does engender trust, however, as evidenced by support for H2. Relationship commitment and trust are positively correlated (H3). This result is consistent with earlier findings (Morgan \& Hunt, 1994) and seems to hold in a cross-border relationship. Relationship commitment contributes to flexibility (H4). Committing resources is a factor that supports the ability to be flexible. However, the link between trust and flexibility (H5) is not supported, as a trusting relationship does not directly contribute to a flexible relationship. The ability to be flexible does lead to satisfaction (H6) and a learning environment helps to support the flexibility of the manufacturer $(\mathrm{H} 7)$.

Interestingly, the relationship between learning orientation and satisfaction with the relationship proved to be statistically significant, however, contrary to the hypothesized positive relationship, the relationship is 
Table 4. Results of Structural Equations Analysis for the Hypothesized Model.

\begin{tabular}{|c|c|c|c|c|}
\hline \multirow[b]{2}{*}{ Path } & \multirow[b]{2}{*}{$\begin{array}{l}\text { Std. Path } \\
\text { Coefficient }\end{array}$} & \multirow[b]{2}{*}{ t-Value } & \multicolumn{2}{|c|}{ Hypotheses } \\
\hline & & & Supported & $\begin{array}{c}\text { Not Supported } / \\
\text { Rejected }\end{array}$ \\
\hline \multicolumn{5}{|l|}{ Structural paths } \\
\hline $\begin{array}{l}\text { Learning orientation } \\
\rightarrow \quad \text { relationship } \\
\text { commitment }\end{array}$ & 0.148 & 1.262 & & $\mathrm{H} 1$ \\
\hline $\begin{array}{l}\text { Learning orientation } \\
\quad \rightarrow \quad \text { trust }\end{array}$ & 0.251 & $2.325^{*}$ & $\mathrm{H} 2$ & \\
\hline $\begin{array}{l}\text { Learning orientation } \\
\quad \rightarrow \quad \text { flexibility }\end{array}$ & 0.294 & $2.695^{*}$ & $\mathrm{H} 7$ & \\
\hline $\begin{array}{l}\text { Learning orientation } \\
\qquad \rightarrow \text { satisfaction }\end{array}$ & -0.585 & $-3.500^{*}$ & H8 (-) & \\
\hline $\begin{array}{l}\text { Relationship } \\
\text { commitment } \rightarrow \\
\text { flexibility }\end{array}$ & 0.738 & $5.019^{*}$ & $\mathrm{H} 4$ & \\
\hline Trust $\rightarrow$ flexibility & 0.125 & 1.091 & & H5 \\
\hline Flexibility $\rightarrow$ satisfaction & 0.212 & $9.491^{* *}$ & H6 & \\
\hline \multicolumn{5}{|l|}{ Correlated variables } \\
\hline $\begin{array}{l}\text { Relationship } \\
\text { commitment } \leftarrow \rightarrow \\
\text { trust }\end{array}$ & 0.800 & $6.614^{* *}$ & $\mathrm{H} 3$ & \\
\hline \multicolumn{5}{|l|}{ Model fit statistics } \\
\hline$\chi^{2}(\mathrm{df})$ & $292.863(127)$ & & & \\
\hline Satorra-Bentler Scaled $\chi^{2}$ & $244.744(127)$ & & & \\
\hline $\begin{array}{l}\text { Bentler-Bollen non- } \\
\text { normed fit index } \\
\text { (BBNFI) }\end{array}$ & 0.880 & & & \\
\hline $\begin{array}{l}\text { Comparative fit index } \\
\text { (CFI) }\end{array}$ & 0.901 & & & \\
\hline Bollen IFI & 0.903 & & & \\
\hline $\begin{array}{l}\text { Root mean-square of } \\
\text { approximation } \\
\text { (RMSEA) }\end{array}$ & 0.083 & & & \\
\hline
\end{tabular}

negative. Encouraging a learning environment between the manufacturer and foreign distributor does not directly translate into satisfaction with the relationship. The relationship between the manufacturer and foreign distributor may require more tangible outcomes before the manufacturer is satisfied. On the other hand, if the manufacturer develops a learning 


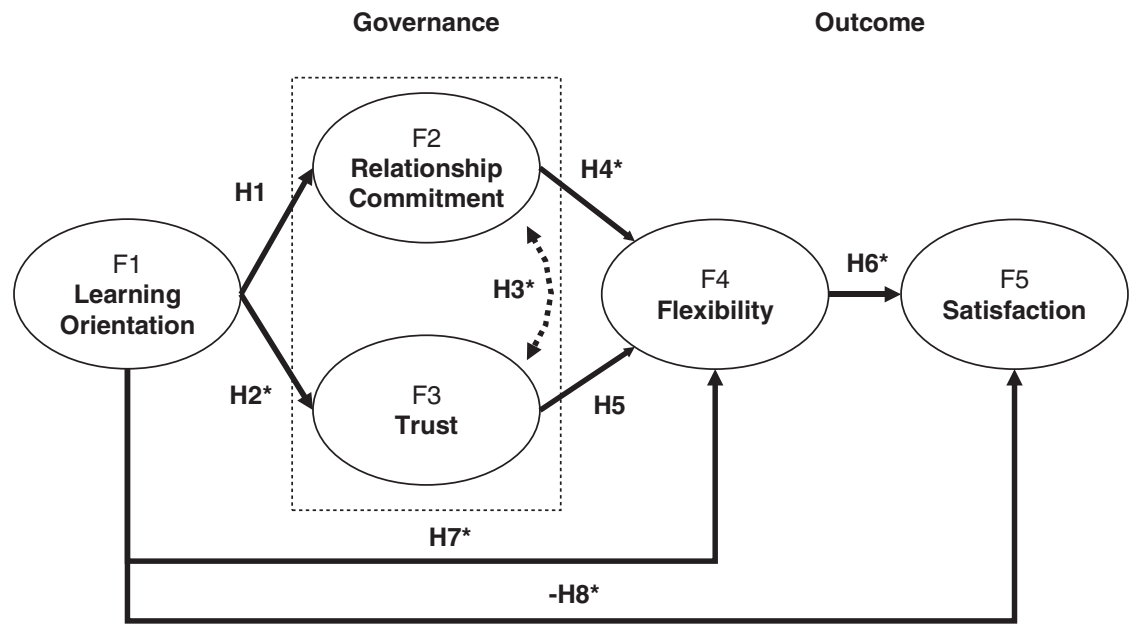

Fig. 2. Hypothesized Relationships. *Indicates Supported Hypotheses (see Table 4. for details), all Correlations Significant at 0.01, dotted-line between F2 and F3 Refers to Correlational Relationship. F1-F5 Sig. Negative Relationship (hypothesized as + rel).

environment, the foreign distributor may not reciprocate by readily sharing its knowledge. This situation could lead to the manufacturer's dissatisfaction with the relationship.

\section{CONCLUSION AND IMPLICATIONS}

This study investigates whether relational governance mechanisms can help exporting manufacturers create a cooperative and learning environment to offset its partner's (foreign distributor) opportunism while contributing to relationship satisfaction and the organization's market flexibility. Exporting manufacturers may wish to look for alternatives to risky and often expensive tactics such as contract enforcement or forward integration. Forward integration involves substantial increases in market commitment which, while suggested in the internationalization theory of the firm (Johanson \& Vahlne, 1977; also Karunaratna \& Johnson, 1997), may not represent export manufacturers' optimal choice. The findings of this study suggest that relational governance mechanisms help to achieve satisfaction with the relationship and flexibility in the dynamic international environment. 
However, certain components of the governance mechanism influence the outcomes differently in this context. The relationship commitment component increases the manufacturer's flexibility because the manufacturer has a more tangible perspective of the foreign distributor's contribution to the relationship. For example, the foreign distributor helps to promote the manufacturer's product or helps to establish the product in the appropriate distribution channel. These tangible elements of governance illustrate the manufacturer's ability to monitor the distributor's contribution to the relationship. However, the manufacturer may not be able to completely monitor the actions of the foreign distributor. This aspect of governance is demonstrated by the lack of connection between trust and flexibility. Essentially, the manufacturer may not be familiar with the host environment and would therefore not be able to understand the intangible relational factors associated with flexibility or the distributor's contribution to the manufacturer's success in the market (e.g., communication associated with processes, the necessary adjustments that the distribution has to make in the environment). The implication is that cultural distance plays a role in relational governance.

Learning orientation is important to developing trust, although it is not necessary to have a trusting relationship in order to obtain flexibility. Learning orientation does contribute to flexibility directly but a learning environment does not satisfy the manufacturer's perspective of the relationship. In the international channel context, the manufacturer is willing to learn as much about the environment as possible, yet the foreign distributor may not be as forthcoming. Perhaps the foreign distributor does not reciprocate by sharing market knowledge but would rather keep this information close to ensure that it remains valuable to the manufacturer. This situation may lead to the manufacturer's dissatisfaction with the relationship. Relationship issues among firms in dedicated relationships are important to examine. The desire to understand how these relationships are governed is due to a substantial increase in global competitive and environmental challenges (Palmer, 2002) and the notion that active relationship management may help to overcome the distance to the partners and downstream customers.

Conceptually, the resource-based view provides a foundation upon which to build a model of governance issues in manufacturer-distributor interaction. Relationship-specific investments, as expressed in the governance of commitment and trust, are seen to contribute to satisfying relationships and flexibility in the market, thus helping in the development of global strategy (Kogut, 1985) and supporting the creation of competitive advantage (Hamel, Doz, \& Prahalad, 1989). The relational governance mechanisms 
(i.e., commitment and trust) represent both formal and relational tools, which can be exercised by a manufacturer to achieve desired outcomes (e.g., flexibility). Learning orientation is seen as a prerequisite to the successful governance of manufacturer-distributor interaction. Manufacturers, who are not openly striving to develop behavioral and organizational characteristics to understand, interpret, and respond to environmental characteristics will not be able to develop a governance mode with their distributor. Relationship satisfaction outcomes will result in lower levels, since willingness to commit assets, share risks, or continue in a long-term relationship is not fully demonstrated. Consequently, partnering manufacturers and distributors will miss out on a 'comfort zone', i.e., experience lower levels of stability and higher levels of dissatisfaction. The strategic asset of 'flexibility' in interaction with their distributors will suffer as well. 'Flexibility' is a critical capability that allows a company to adapt quickly to changes in uncertain foreign environments; hence, a flexible manufacturer will be satisfied with this particular outcome in the international market. In other words, the company's ability to react to market dynamism may be a competitive advantage that could be attributed to working with the foreign distributor. Therefore, the manufacturer would be satisfied with the relationship.

Our conceptual research model is designed to appeal to both managers, involved in international distribution systems as well as scholars, interested in improving international distribution relationships and enhancing relationship marketing activities.

\section{LIMITATIONS}

The findings from this study need to be evaluated in the context of several limitations. Additional empirical investigations might attempt to confirm or extend the proposed relationships thus contributing to generalizing the framework to various national and international contexts. It is very desirable to replicate the study with a range of firms and industries in an attempt to offset the sampling bias; which potentially limits the generalizability of this study. This research also failed to demonstrate the hypothesized direct link between learning orientation and satisfaction. It should be interesting to learn whether this is, in fact, specific to the study or indicates a general pattern. This study also suffers from a small sample size which does not allow for tests of moderating effects such as geographic region or international experience. Future research is needed to evaluate these interaction effects, provided the availability of larger samples. 


\section{NOTES}

1. The discussion follows the organization of the figure and reads from left to right.

\section{REFERENCES}

Aharoni, Y. (1966). The foreign investment decision process. Boston, MA: Harvard University Press.

Anderson, E., \& Weitz, B. (1992). The use of pledges to build and sustain commitment in distribution channels. Journal of Marketing Research, 29(1), 18-43.

Anderson, J. C., \& Gerbing, D. W. (1988). Structural equation modeling in practice: A review and recommended two-step approach. Psychological Bulletin, 103(3), 411-423.

Anderson, J. C., \& James, N. A. (1990). A model of distributor firm and manufacturer firm working partnerships. Journal of Marketing, 54(1), 42-58.

Armstrong, J. S., \& Overton, T. S. (1977). Estimating nonresponse bias in mail surveys. Journal of Marketing Research, 14(3), 396-402.

Aulakh, P. S., Kotabe, M., \& Sahay, A. (1996). Trust and performance in cross-border marketing partnerships: A behavioral approach. Journal of International Business Studies, 27(5), 1005-1032.

Bagozzi, R. P., \& Yi, Y. (1988). On the evaluation of structural equation models. Journal of the Academy of Marketing Science, 16(1), 74-94.

Barney, J. B., \& Hansen, M. H. (1994). Trustworthiness as a source of competitive advantage. Strategic Management Journal, 15, 175-191.

Bartlett, C. A., \& Ghoshal, S. (1998). Beyond strategic planning to organization learning: Lifeblood of the individualized corporation. Strategy \& Leadership, 26(1), 34-39.

Baumgartner, H., \& Homburg, C. (1996). Applications of structural equation modeling in marketing and consumer research: A review. International Journal of Research in Marketing, 13(2), 139-161.

Bello, D. C., \& Gilliland, D. I. (1997). The effect of output controls, process controls, and flexibility on export channel performance. Journal of Marketing, 61(1), 22-38.

Bentler, P. M., \& Wu, E. J. C. (2003). EQS 6.0 user's guide. Encino, CA: Multivariate Software Inc.

Boersma, M. F., Buckley, P. J., \& Ghauri, P. N. (2003). Trust in international joint venture relationships. Journal of Business Research, 56(12), 1031-1042.

Bollen, K. A. (1989). Structural equations with latent variables. New York, NY: Wiley.

Cavusgil, S. T. (1984). Organizational characteristics associated with export activity. The Journal of Management Studies, 21(1), 3-22.

Cavusgil, S. T. (1998). Perspectives: Knowledge development in international marketing. Journal of International Marketing, 6(2), 103-112.

Celly, K. S., \& Frazier, G. L. (1996). Outcome-based and behavior-based coordination efforts in channel relationships. Journal of Marketing Research, 33(May), 200-210.

Churchill, G. A. (1979). A paradigm for developing better measures of marketing constructs. Journal of Marketing Research, 16(1), 64-73.

Conn, H. P., \& Yip, G. S. (1997). Global transfer of critical capabilities. Business Horizons, $40(1), 22-31$. 
Cova, B., \& Salle, R. (2000). Rituals in managing extrabusiness relationships in international project marketing: A conceptual framework. International Business Review, 9(6), $669-685$.

Cullen, J. B., Johnson, J. L., \& Sakano, T. (1995). Japanese and local partner commitment to IJVs: Psychological consequences of outcomes and investments in the IJV relationship. Journal of International Business Studies, 26(1), 91-115.

Cyert, R. D., \& March, J. G. (1963). A behavioral theory of the firm. Englewood Cliffs, NJ: Prentice-Hall.

DeVellis, R. F. (1991). Scale development - theory and applications (Applied Social Research Methods Series), Vol. 26. Neybury Park: Sage.

Doney, P. M., \& Cannon, J. P. (1997). An examination of the nature of trust in buyer-seller relationships. Journal of Marketing, 61(2), 35-51.

Drucker, P. F. (1995). The information executives truly need. Harvard Business Review, 73(1), 54-63.

Dwyer, F. R., \& Oh, S. (1988). A transaction cost perpective on vertical contractual structures. Journal of Marketing, 52(2), 21-34.

Dwyer, F. R., Schurr, P. H., \& Oh, S. (1987). Developing buyer-seller relations. Journal of Marketing, 51(2), 11-28.

Dyer, J. H., \& Chu, W. (2000). The determinants of trust in supplier-automaker relationships in the U.S., Japan, and Korea. Journal of International Business Studies, 31(2), 259-285.

Dyer, J. H., \& Singh, H. (1998). The relational view: Cooperative strategy and sources of interorganizational competitive advantage. The Academy of Management Review, 23(4), 660-679.

Evans, J. S. (1991). Strategic flexibility for high technology manoeuvres: A conceptual framework. The Journal of Management Studies, 28(1), 69-89.

Fornell, C., \& Larcker, D. F. (1981). Evaluating structural equation models with unobservable variables and measurement error. Journal of Marketing Research, 18(1), 39-50.

Forsgren, M. (2002). The concept of learning in the uppsala internationalization process model: A critical review. International Business Review, 11(3), 257-277.

Frazier, G. L., \& Kale, S. H. (1989). Manufacturer-distributor relationships: A sellers' versus buyers' market perspective. International Marketing Review, 6(6), 7-26.

Ganesan, S. (1994). Determinants of long-term orientation in buyer-seller relationships. Journal of Marketing, 58(2), 1-19.

Gerbing, D. W., \& Anderson, J. C. (1988). An updated paradigm for scale development incorporating unidimensionality and its assessment. Journal of Marketing Research, 25(2), $186-192$.

Geyskens, I., Steenkamp, J-B. E. M., \& Kumar, N. (1998). Generalizations about trust in marketing channel relationships using meta-analysis. International Journal of Research in Marketing, 15(3), 223-248.

Gold, A. H., Malhotra, A., \& Segars, A. H. (2001). Knowledge mangement: An organizational capabilities perspective. Journal of Management Information Systems, 18(1), 185-214.

Gounaris, S. P., \& Venetis, K. (2002). Trust in industrial service relationships: Behavioral consequences, antecedents and the moderating effect of the duration of the relationship. Journal of Services Marketing, 16(7), 636-655.

Gruen, T. W., Summers, J. O., \& Acito, F. (2000). Relationship marketing activities, commitment, and membership behaviors in professional associations. Journal of Marketing, 64(3), 34-49. 
Gundlach, G. T., Achrol, R. S., \& Mentzer, J. T. (1995). The structure of commitment in exchange. Journal of Marketing, 59(1), 78-92.

Hadjikhani, A. (1997). A note on the criticisms against the internationalization process model. Management International Review, 37(2), 43-66.

Hamel, G. (1991). Competition for competence and inter-partner learning within international strategic alliances. Strategic Management Journal, 12, 83-103.

Hamel, G., Doz, Y. L., \& Prahalad, C. K. (1989). Collaborate with your competitors - and win. Harvard Business Review, 67(1), 133-139.

Harrigan, K. R. (1988). Joint ventures and competitive strategy. Strategic Management Journal, 9(2), 141-158.

Heide, J. B. (1994). Interorganizational governance in marketing channels. Journal of Marketing, 58(1), 71-85.

Heide, J. B., \& John, G. (1992). Do norms matter in marketing relationships? Journal of Marketing, 56(2), 32-44.

Homburg, C., \& Giering, A. (1996). Konzeptualisierung und Operationalisierung Komplexer Konstrukte - Ein Leitfaden Für Die Marketingforschung. Marketing ZFP - Zeitschrift für Forschung und Praxis, 1(1), 5-24.

Huber, G. P. (1991). Organizational learning: The contributing processes and the literatures. Organization Science, 2(1), 88-115.

Hult, G. T. M., \& Ferrell, O. C. (1997). A global learning organization structure and market information processing. Journal of Business Research, 40(2), 155-166.

Ibeh, K., Brock, J. K.-U., \& Zhou, Y. J. (2004). The drop and collect survey among industrial populations: Theory and empirical evidence. Industrial Marketing Management, 33(2), 155-165.

Jobber, D., Saunders, J., \& Mitchell, V.-W. (2004). Prepaid monetary incentive effects on mail survey response. Journal of Business Research, 57(4), 347-350.

Johanson, J., \& Vahlne, J.-E. (1977). The internationalization process of the firm - a model of knowledge development and increasing foreign market commitments. Journal of International Business Studies, 8(1), 23-32.

Johanson, J., \& Vahlne, J.-E. (1990). The mechanism of internationalisation. International Marketing Review, 7(4), 11-24.

Karunaratna, A. R., \& Johnson, L. W. (1997). Initiating and maintaining export channel intermediary relationships. Journal of International Marketing, 5(2), 11-32.

Kim, W. C., \& Mauborgne, R. A. (1993). Effectively conceiving and executing multinationals' worldwide. Journal of International Business Studies, 24(3), 419-449.

Klein, S., Frazier, G. L., \& Roth, V. J. (1990). A transaction cost analysis model of channel integration in. Journal of Marketing Research, 27(2), 196-208.

Klein, S., \& Roth, V. J. (1990). Determinants of export channel structure: The effects of experience and psychic distance reconsidered. International Marketing Review, 7(5), 27-38.

Kogut, B. (1985). Designing global strategies: Comparative and competitive value-added chains. Sloan Management Review, 26(4), 15-20.

Lambe, C. J., Spekman, R. E., \& Hunt, S. D. (2000). Interimistic relational exchange: Conceptualization and propositional development. Journal of the Academy of Marketing Science, 28(2), 212-225.

Ling-yee Li, E., \& Ogunmokum, G. (2000). The effect of flexibility on export venture performance. Journal of Global Marketing, 14(3), 99-126. 
Lusch, R. F., \& Brown, J. R. (1996). Interdependency, contracting, and relational behavior in marketing channels. Journal of Marketing, 60(4), 19-38.

Lyles, M. A., \& Schwenk, C. R. (1994). The impact of organizational learning on joint venture formations. International Business Review, 3(4), 459-476.

Macneil, I. R. (1980). The new social contract: An inquiry into modern contractual relations. New Haven, CT: Yale University Press.

Mayer, R. C., Davis, J. H., \& Schoorman, F. D. (1995). An integration model of organizational trust. Academy of Management Review, 20(3), 709-734.

Moen, Ø. (1999). The relationship between firm size, competitive advantages and export performance revisited. International Small Business Journal, 18(1), 53-72.

Moorman, C., Deshpande, R., \& Zaltman, G. (1993). Factors affecting trust in market research relationships. Journal of Marketing, 57(1), 81-101.

Morgan, R. M., \& Hunt, S. D. (1994). The commitment-trust theory of relationship m arketing. Journal of Marketing, 58(3), 20-38.

Nevin, J. R. (1995). Relationship marketing and distribution channels: Exploring fundamental issues. Academy of Marketing Science, 23(4), 327-334.

Nonaka, I. (1994). A dynamic theory of organizational knowledge creation. Organization Science, 5(1), 14-37.

Noordewier, T. G., John, G., \& Nevin, J. R. (1990). Performance outcomes of purchasing arrangments in industrial buyervendor relationships. Journal of Marketing, 54(4), 80-93.

Palmer, A. (2002). The evolution of an idea: An environmental explanation of relationship marketing. Journal of Relationship Marketing, 1(1), 79-94.

Parkhe, A. (1998a). Building trust in international alliances. Journal of World Business, 33(4), 417-437.

Parkhe, A. (1998b). Understanding trust in international alliances. Journal of World Business, 33(3), 219-240.

Penrose, E. (1959). The theory of the growth of the firm. London: Blackwell.

Ring, P. S., \& Van De Ven, A. H. (1992). Structuring cooperative relationships between organizations. Strategic Management Journal, 13(7), 483-489.

Roath, A. S., Miller, S. R., \& Cavusgil, S. T. (2002). A conceptual framework of relational governance in foreign distributor relationships. International Business Review, 11(1), $1-16$.

Rosson, P. J., \& Ford, I. D. (1982). Manufacturer-overseas distributor relations and export performance. Journal of International Business Studies, 13(2), 57-72.

Roxenhall, T., \& Ghauri, P. (2004). Use of the written contract in long-lasting business relationships. Industrial Marketing Management, 33(3), 261-268.

Sabel, C. F. (1993). Studied trust: Building new forms of cooperation in a volatile economy. Human Relations, 46(9), 1133-1170.

Sanchez, R. (1995). Strategic flexibility in product competition. Strategic Management Journal, 16(Special issue), 135-159.

Satorra, A., \& Bentler, P. M. (1988). Scaling corrections for statistics in covariance structure analysis, Ucla Statistics Series \#2. Los Angeles, CA: University of California.

Satorra, A., \& Bentler, P. M. (1994). Corrections to test statistics and standard errors in covariance structure analysis. In: A. von Eye \& C. C. Clogg (Eds), Latent variables analysis: Applications for developmental research (pp. 399-419). Thousand Oaks, CA: Sage. 
Slater, S. F., \& Narver, J. C. (1995). Market orientation and the learning organization. Journal of Marketing, 59(3), 63-74.

Theoharakis, V., \& Hooley, G. (2003). Organizational resources enabling service responsiveness: Evidence from Greece. Industrial Marketing Management, 32(8), 695-702.

Weitz, B. A., \& Jap, S. D. (1995). Relationship marketing and distribution channels. Journal of the Academy of Marketing Science, 23(4), 305-320.

Wilson, D. T. (1995). An integrated model of buyer-seller relationships. Journal of the academy of marketing science, 23(4), 335-345.

Wilson, E. J. (1999). Research practice in business marketing: A comment on response rate and response bias. Industrial Marketing Management, 28(3), 257-260.

Zaheer, A., McEvily, B., \& Perrone, V. (1998). Does trust matter? Exploring the effects of interorganizational and interpersonal trust on performance. Organization Science, 9(2), $141-159$.

Zaheer, A., \& Venkatraman, N. (1995). Relational governance as an interorganizational strategy: An empirical test of the role of trust in economic exchange. Strategic Management Journal, 16(5), 373-393. 